Article

\title{
Physicochemical Composition and Nutritional Properties of Deer Burger Enhanced with Healthier Oils
}

\author{
Marcio Vargas-Ramella ${ }^{1,2}{ }^{-}$, Paulo E. S. Munekata ${ }^{2}$, Mirian Pateiro ${ }^{2}{ }^{\circ}$, Daniel Franco ${ }^{2}{ }^{\mathbb{D}}$, \\ Paulo C. B. Campagnol ${ }^{3}$, Igor Tomasevic ${ }^{4}\left(\mathbb{D}\right.$, Rubén Domínguez $^{2} \mathbb{D}$ and José M. Lorenzo ${ }^{2, *(\mathbb{D})}$ \\ 1 Centro de Educação Superior da Região Sul-CERES da Universidade do Estado de Santa Catarina, \\ Chapecó, Santa Catarina 89.800-000, Brazil; marcio.ramella@hotmail.com \\ 2 Centro Tecnológico de la Carne de Galicia, Rúa Galicia No 4, Parque Tecnológico de Galicia, San Cibrao das \\ Viñas, 32900 Ourense, Spain; paulosichetti@ceteca.net (P.E.S.M.); mirianpateiro@ceteca.net (M.P.); \\ danielfranco@ceteca.net (D.F.); rubendominguez@ceteca.net (R.D.) \\ 3 Department of Food Science and Technology (DTCA), Universidade Federal de Santa Maria, Santa Maria \\ CEP 97105-900, Rio Grande do Sul, Brazil; paulocampagnol@gmail.com \\ 4 Department of Animal Source Food Technology, Faculty of Agriculture, University of Belgrade, Nemanjina 6, \\ Belgrade 11080, Serbia; tbigor@agrif.bg.ac.rs \\ * Correspondence: jmlorenzo@ceteca.net
}

Received: 4 April 2020; Accepted: 28 April 2020; Published: 4 May 2020

check for updates

\begin{abstract}
Deer meat is characterized by low fat and cholesterol contents and high amounts of protein and polyunsaturated fatty acids. In this regard, the aim of this work was to assess the influence of pork backfat substitution by healthier oils on chemical composition, fatty acid profile, texture profile and sensory analysis of deer burger. In addition, $\mathrm{pH}$, color parameters and lipid oxidation were evaluated at $0,6,12$ and 18 days of storage. For this study, four different treatments of deer burgers-100\% pork backfat, 100\% tiger nut oil, 100\% chia oil, and 100\% linseed oil-were elaborated. The fat replacement reduced fat and protein contents and increased moisture amounts, whereas ashes and texture parameters of deer burgers were not affected. Fatty acid profile was significantly improved with the animal fat replacement. In this regard, a significant decrease in saturated fatty acids was found in all reformulated batches, whereas in chia and linseed burger samples a dramatic increase in polyunsaturated fatty acids, omega- 3 content and a reduction of $n-3 / n-6$ ratio was observed. In the deer burger prepared with tiger nut oil a significant increase in monounsaturated fatty acids was found. Another important aspect is that the replacement of animal fat by tiger nut or linseed oil emulsion did not affect the global acceptance of deer burgers. Regarding color parameters, redness was the most affected during the whole display presenting a reduction around $50 \%$ after 18 days of storage. On the other hand, thiobarbituric acid reactive substances (TBARS) values were also affected by fat replacement and storage time, observing the highest values $(2.43 \mathrm{mg} \mathrm{MDA} / \mathrm{kg})$ in deer burgers prepared with chia at the end of refrigerated period. Finally, from a commercial point of view, the possibility of making claims such as "low fat burgers", "reduced saturated fat" or "high content of omega-3" makes the reformulated burgers more attractive to the consumer.
\end{abstract}

Keywords: lipid oxidation; healthy meat product; tiger nut; chia; linseed; sensorial analysis

\section{Introduction}

Based on estimations by the World Health Organization (WHO), approximately 462 million adults worldwide were underweight, while 1.9 billion were either overweight or obese [1]. In the last few years, most countries have seen an unhealthy diet high in saturated fatty acids (SFA) contributing to 
the overweight population and chronic disorders, particularly ischemic heart disease and stroke [1-4]. To reduce all forms of malnutrition and the incidence of such diseases, recommendations for optimal intake of total fat and unsaturated fatty acids have been proposed by many governments [2,3,5].

Food reformulation is included in nutrition action plans of many countries, and currently, almost every European Union (EU) country has at least one plan or program on food/nutrition and health for salt-fat-sugar reduction [2]. Additionally, the increased intention of consumers to buy healthier meat products with favorable nutritional information has given rise to the reformulation of some traditional meat products [6,7]. From the consumer point of view, innovation should not assume the loss of sensory characteristics of the traditional product [8]. Thus, meat product reformulation using vegetable or marine oils as animal fat replacers [9-14] could be a good strategy. Among the multiple vegetable oils, chia and linseed oils are characterized by having a high content of $\alpha$-linolenic acid (around 60\%), high PUFA/SFA ratio (up to 7.40) and a n-6/n-3 ratio that can reach 0.30, which are used in several studies $[8,9,15,16]$. In contrast, tiger nut is an untapped source of health food with highly nutritional values and a relevant source of monounsaturated fatty acids (MUFA) such as oleic acid $(67 \%-69 \%)[9,17-19]$.

Spain is the second largest world producer of deer venison which mainly exports meat from hunted animals. The official data on deer harvested seems to underestimate the real production that accounted for 235,000 cervids harvested in 2018 (144,134 deer, 66,737 roe deer and 24,337 fallow deer; MAPA [20]). At a conservative estimate of $50 \mathrm{~kg} /$ carcass, 11,750 tons of deer meat are exported (co-products not included) according to industry estimates, but even the official figures reach 14,400 tons, which is composed of 11,530 tons of red deer venison, 1668 tons of roe deer, and 1241 tons of fallow deer venison [20]. In addition, deer (venison) is raised under natural conditions and has enjoyed a rise in popularity among consumers in recent years [21,22]. It is also worth noting that deer meat has excellent nutritional characteristics. This meat has low fat and cholesterol contents and high amounts of protein, essential amino acids and minerals [21,23-26]. Additionally, the fatty acids profile of the deer meat is characterized by high amounts of PUFA ( $43.80 \mathrm{~g} / 100 \mathrm{~g}$ total fatty acids) and long-chain n-3 [9,24-26], which have positive effects on human health.

Among the meat products, burgers are consumed worldwide, usually produced from $70 \%$ to $75 \%$ of meat and $25 \%$ to $30 \%$ of fat $[27,28]$. Other studies have shown that beef burger contains from $9 \%$ to $20 \%$ animal fat in formulation, with high SFA content (31\%-42\%) [16,29-31]. Pork backfat is commonly used as a fat source in meat products. However, its nutritional quality is questioned, since it contains an unfavorable fatty acid profile with a high level of SFA and high n-6/n3 ratio [16,32-34]. Thus, several researchers indicated that the partial or total replacement of pork back fat by vegetable or marine oils resulted in a reduction of both, total fat and SFA contents $[9,10,12,14,31]$. Additionally, the content of cholesterol showed a significant reduction with the animal fat replacement by vegetable oils [14].

Thus, due to the nutritional quality that vegetable oils can provide to consumers by increasing the $\alpha$-linolenic or oleic acid in meat products with the animal fat replacement, the present study aimed to reformulate deer burgers to make them healthier through the total replacement of pork back fat by linseed, chia or tiger nut oils emulsions and evaluate its physicochemical, nutritional and sensory characteristics.

\section{Materials and Methods}

\subsection{Preparation of Vegetable Oil Emulsion}

The study was performed in the Centro Tecnolóxico da Carne (CTC) de Galicia (San Cibrao das Viñas, Spain). In order to prepare the vegetable oil emulsion with Prosella (Prosella VG NF4, Colin Ingrédients, Mittelhausen, France), its elaboration was performed one day before the processing of burgers [31,35]. The Prosella powder was composed of jellifying agents (calcium sulphate and sodium alginate), wheat glucose syrup (7.4\%), a stabilizer (disodium diphosphate, added $\mathrm{P}_{2} \mathrm{O}_{5}: 9.58 \%$ ) and an antioxidant (sodium ascorbate), which retain oils in its structure and can be used as animal fat 
replacer. For oil emulsions preparation, water $(56 \mathrm{~g} / 100 \mathrm{~g})$ and vegetable oil $(37.3 \mathrm{~g} / 100 \mathrm{~g})$ were mixed for $1 \mathrm{~min}$ in a bowl cutter (Sirman, mod C15VV, Marsango, Italy). The Prosella powder (6.7 g/100 g) was added and homogenized during $3 \mathrm{~min}$ and then left to rest for $2 \mathrm{~h}$, then the mixture was refrigerated at $4{ }^{\circ} \mathrm{C}$ until needed.

\subsection{Deer Burgers Manufacture}

Four different formulations were processed: control (containing pork back fat as lipid source ( $3 \mathrm{~g} / 100 \mathrm{~g}$; formulation with low amount of fat added)) and three experimental batches in which animal fat was replaced by vegetable oil emulsion (immobilized in prosella gel) ( $3 \mathrm{~g} / 100 \mathrm{~g}$ ) (tiger nut oil (TIG); chia oil (CHI); linseed oil (LIN)). The other ingredients used in all formulations were deer lean meat $(87.8 \mathrm{~g} / 100 \mathrm{~g})$, salt $(1.2 \mathrm{~g} / 100 \mathrm{~g})$ and water $(8 \mathrm{~g} / 100 \mathrm{~g})$. Prime cuts of foreshank from hunted deer supplied by Cárnicas Dibe (Cáceres, Spain) and pork fat were used in burger processing. All visible fat and connective tissue were removed manually from the meat. For burger processing, firstly primal cuts of foreshank and pork fat and/or vegetable oil emulsions were ground through an $8 \mathrm{~mm}$ and $6 \mathrm{~mm}$ diameter mincing plate in a refrigerated mincer machine (La Minerva, Bologna, Italy), respectively. The meat batter was mixed together with the remaining ingredients until complete homogenization and shaped in a burger format. The different treatments were shaped $(10 \mathrm{~cm}$ diameter and $1 \mathrm{~cm} \mathrm{height)}$ in a manual burger machine. A total of $2 \mathrm{~kg}$ of mass was prepared, resulting in 25 burgers in each treatment and weighing $80 \mathrm{~g}$ each.

After processing, burgers were packed under modified atmosphere $\left(80 \% \mathrm{O}_{2}\right.$ and $\left.20 \% \mathrm{CO}_{2}\right)$ in $300 \mathrm{~mm}$ thick PET-EVOH-PE trays, sealed with multilayer PE-EVOH-PE film (74 mm thick, permeability $<2 \mathrm{~mL} / \mathrm{m}^{2}$ bar/day (Viduca, Alicante, Spain)) using a heat sealer (LARI3/Pn T-VG-R-SKIN, Ca.Ve.Co., Palazzolo, Italy). The samples were stored at $2 \pm 1{ }^{\circ} \mathrm{C}$ under light, simulating the conditions from the supermarket and analyzed at 0,6,12 and 18 days of storage (proximate composition, fatty acids, texture profile analysis and sensory analysis on day $0 ; \mathrm{pH}$, color parameters and oxidative stability on days $0,6,12$ and 18). On sampling days, twenty samples (five for each batch) were collected and evaluated for their proximate composition, physicochemical parameters, fatty acids profile and sensory characteristics. The entire experiment was replicated in two different weeks.

\subsection{Proximate and Physicochemical Analysis of Deer Burgers}

\subsubsection{Proximate Composition, Carbohydrates and Energy Content}

The proximate composition of the different deer burger treatments were evaluated according to International Organization for Standards (ISO), for protein [36], moisture [37] and ash [38] content, while total fat was determined according to the Approved Procedure Am 5-04, established by the American Oil Chemists' Society [39].

\subsubsection{Color and $\mathrm{pH}$}

Color parameters $\left(\mathrm{L}^{*}\right.$-brightness, $\mathrm{a}^{*}$ - greenness/redness and $\mathrm{b}^{*}$-blueness/yellowness) were measured in the CIELAB space using a portable colorimeter (CR-600d, Minolta Co. Ltd., Osaka, Japan). The device was set to pulsed xenon arc lamp, $10^{\circ}$ viewing angle geometry, and $8 \mathrm{~mm}$ aperture. The $\mathrm{pH}$ was measured in the deer burgers using a digital pH-meter (Hanna Instruments, Eibar, Spain) equipped with a penetration glass probe.

\subsubsection{Cooking Loss and Texture Profile Analysis}

For analysis of cooking loss and instrumental texture, the burgers were cooked using vacuum package bags and introduced in a water bath with automatic temperature control (JP Selecta, Precisdg, Barcelona, Spain) until they reached an internal temperature of $70{ }^{\circ} \mathrm{C}$, monitoring the heat by a thermocouples type K (Comark, PK23M, St Neots, UK) connected to a data logger (Comark Dilligence EVG, N3014). Cooking loss was measured by difference in weight between cooked and raw samples. 
Texture profile analysis (TPA) (hardness, springiness, cohesiveness, gumminess and chewiness) was measured by compressing to $60 \%$ (cylindric probe with flat surface area of $19.85 \mathrm{~cm}^{2}$ ) and the force-time curves were recorded at $3.33 \mathrm{~mm} / \mathrm{s}$ crosshead speed. The texture parameters were obtained using Texture Exponent 32 software (version 1.0.0.68, StableMicro Systems, Vienna Court, UK).

\subsubsection{Lipid Oxidation}

The thiobarbituric acid reactive substances (TBARS) index (2-thiobarbituric acid; secondary products of the lipid oxidation) was determined [40] to assess the degree of lipid oxidation in the different samples. Thiobarbituric acid reactive substances (TBARS) values were calculated from a standard curve of malonaldehyde (MDA) with 1,1,3,3-tetraethoxipropane (TEP) and expressed as mg $\mathrm{MDA} / \mathrm{kg}$ sample.

\subsection{Fatty Acid Analysis of Deer Burger}

For fatty acid analysis, total fat was extracted following the method described by Bligh and Dyer [41] with the modifications proposed by Barros et al. [31].

The fatty acids were transesterified according to the procedure previously described by Barros et al. [31]: for the fatty acids analysis, twenty milligrams of extracted fat dissolved in $1 \mathrm{~mL}$ of toluene were transesterified with sodium methoxide and $\mathrm{H}_{2} \mathrm{SO}_{4}$-methanol solution. For the extraction of fatty acid methyl esters, $1 \mathrm{~mL}$ of hexane was added to the samples and the organic phase was then transferred to an appropriate GC vial.

Separation and quantification of fatty acids methyl esters (FAMEs) were carried out using a gas chromatograph (GC-Agilent 7890B, Agilent Technologies, Santa Clara, CA, USA) equipped with a flame ionization detector (FID) and PAL RTC-120 auto sampler. For the separation of FAMEs, a DB-23 fused silica capillary column ( $60 \mathrm{~m}, 0.25 \mathrm{~mm}$ i.d., $0.25 \mu \mathrm{m}$ film thickness; Agilent Technologies) was used. Chromatographic conditions were completely detailed in the a previous manuscript [31]. Individual FAMEs were identified by comparing their retention times with those of authenticated standards (FAME Mix-37 components; docosapentaenoic acid (C22:5n-3; DPA); trans-11 vaccenic acid (11t-C18:1; TVA); cis-vaccenic acid (C18:1n-7; CVA) (Supelco, Madrid, Spain) and conjugated linoleic acid (9c,11t-C18:2; CLA) (Matreya)) and the results were expressed as $\mathrm{g} / 100 \mathrm{~g}$ of total fatty acids identified.

\subsection{Sensorial Acceptance Evaluation of Deer Burgers}

Sensory analysis was conducted by 68 consumers (with ages between 29 and 40 y and from both genders) from Ourense (Spain). The treatments were evaluated in raw and cooked samples, to determine whether the panelist liked or disliked the different batches of fat replacement by vegetable oil emulsions in relation to control. Consumers evaluated the deer burgers by the acceptance test using a 7-point hedonic scale, which ranged from "1—disliked much" to "7-liked much", for the following attributes: raw burgers (visual aspect and odor) and cooked burgers (odor cooked burger, flavor, juiciness, fibrous, greasy character and overall acceptability). The burgers were cooked in an oven (Rational Combi Master ${ }^{\circledR}$ Plus CMP61, Landsberg am Lech, Germany) equipped with a core temperature probe, until they reached an internal temperature of $70^{\circ} \mathrm{C}$. The samples were cut in $2 \mathrm{~cm}^{3}$ portions, which were individually wrapped in foil and marked with a random 3-digit code. The samples were kept warm in a heater at $55^{\circ} \mathrm{C}$ until the testing (up to $30 \mathrm{~min}$ ). To avoid the possible effects of the order of presentation, the samples were presented to panel members in a random order [42] and served to panelist together with water and toast.

\subsection{Statistical Analysis}

Statistical analyses were performed using the SPSS statistical software, version 19 (IBM). Normal distribution and homogeneity of variance were previously tested (Shapiro-Wilk). Data were submitted for analysis of variance (ANOVA) and Tukey test, when ANOVA had a significant effect $(p<0.05)$. 
For proximate composition, physicochemical analysis and fatty acids data, treatments were considered as fixed effects and replications (the whole experiment was repeated twice) as a random effect, whereas for sensory acceptance, consumers were additionally included in the model as a random effect (each panelist tasted four samples, one from each formulation, in a single session).

\section{Results and Discussion}

The perception that meat products are good sources of nutrients is gradually giving way to a more negative view, perceived as unhealthy by consumers mainly by the presence of unhealthy constituents in its composition (such as high fat, SFA and cholesterol contents). One strategy that may represent an opportunity for the meat industry to improve this perception is the reformulation of meat products using vegetable oils as fat sources [13,34,43,44]. Additionally, the use of deer meat for making burgers is very limited. Thus, the development of this meat product, with an improved nutritional profile, puts a non-commercialized product on the market.

\subsection{Proximate Composition, Cooking Loss and Texture Parameters of Burgers}

The fat replacement by vegetable oils (tiger nut, chia, and linseed) resulted in a significant increase in moisture $(p<0.01)$ and a decrease in protein $(p<0.05)$ and fat contents $(p<0.05)$, whereas the ash content did not show differences among batches (Table 1). Similar results were found by previous studies for moisture in beef burgers reformulated with canola oil $[27,45]$, in beef $[8,16,27]$ and lamb burgers [35] reformulated with chia and/or linseed oil and in beef burgers with tiger nut oil [31] compared to conventional burgers (high animal fat percentage). In contrast, other authors [46] found for tiger nut pork burgers a decrease $(p<0.05)$ in moisture. In the present case, and as occurs in previous studies with partial replacement of animal fat by vegetable oils added as "prosella" emulsion [31], the increase in moisture was due to the amount of water (56 g/100 g), added to prepare the different emulsions.

Table 1. Proximate composition, cooking loss and texture parameters of deer burgers.

\begin{tabular}{|c|c|c|c|c|c|c|}
\hline \multirow{2}{*}{ Parameters } & \multicolumn{4}{|c|}{ Treatments } & \multirow{2}{*}{ SEM } & \multirow{2}{*}{ Sig. } \\
\hline & $\mathrm{CON}$ & TIG & $\mathrm{CHI}$ & LIN & & \\
\hline \multicolumn{7}{|c|}{ Proximate composition $(\%)$} \\
\hline Moisture & $74.50^{\mathrm{a}}$ & $75.27^{\mathrm{b}}$ & $75.66^{b}$ & $75.94^{b}$ & 0.16 & $* *$ \\
\hline Fat & $3.64^{b}$ & $2.10^{\mathrm{a}}$ & $2.57^{\mathrm{a}}$ & $2.66^{\mathrm{a}}$ & 0.10 & ** \\
\hline Protein & $19.04^{\mathrm{b}}$ & $18.51^{\mathrm{a}}$ & $18.46^{\mathrm{a}}$ & $18.51^{\mathrm{a}}$ & 0.09 & * \\
\hline Ash & 1.99 & 2.02 & 1.97 & 1.90 & 0.03 & n.s. \\
\hline Cooking loss $(\%)$ & $28.31^{b}$ & $27.27^{b}$ & $27.11^{\mathrm{b}}$ & $23.93^{\mathrm{a}}$ & 0.59 & * \\
\hline \multicolumn{7}{|l|}{ TPA test } \\
\hline Hardness (N) & 88.30 & 90.34 & 87.65 & 80.13 & 1.80 & n.s. \\
\hline Springiness (mm) & 0.72 & 0.72 & 0.73 & 0.76 & 0.01 & n.s. \\
\hline Cohesiveness & 0.60 & 0.59 & 0.60 & 0.61 & 0.00 & n.s. \\
\hline Gumminess (N) & 53.68 & 53.44 & 52.75 & 48.12 & 1.17 & n.s. \\
\hline Chewiness $(\mathrm{N} \cdot \mathrm{mm})$ & 39.10 & 39.78 & 39.08 & 35.88 & 0.95 & n.s. \\
\hline
\end{tabular}

a,b Mean values with different letters indicate significant difference $(p<0.05)$; SEM: standard error of the mean; Sig.: Significance: n.s.: Not significant; ${ }^{* *} p<0.01 ;{ }^{*} p<0.05$. Treatments: CON: burgers prepared $100 \%$ pork fat; TIG: burgers prepared with $100 \%$ of pork fat replaced by tiger nut oil; CHI: burgers prepared with $100 \%$ of pork fat replaced by chia oil; LIN: burgers prepared with $100 \%$ of pork fat replaced by linseed oil.

In contrast, the animal fat replacement resulted in a significant $(p<0.05)$ reduction in protein content. This reduction was also reported by other authors in beef burgers with fat replacement by hydrogelled or prosella emulsions [16,31]. However, other researchers did not find this decrease $[8,46,47]$, while the use of pork skin-canola oil mixture resulted in a significant increase in protein content of beef burgers [27]. In our study, the replacement of animal fat by vegetable oil emulsion caused a decrease in protein content of deer burgers which could be related to the fact that animal back fat contains an important 
proportion of protein. In fact, the protein content of pork back fat can be around $8 \%$ [11], whereas the prosella emulsion contains only water, oil, and gelling agents, resulting in a significant reduction in protein.

In similar way to protein content, lipid percentage also decreased with fat animal replacement. This fact was also reported by several researchers in burgers with fat replacement. Heck et al. [16] found a reduction of fat content (up to $50 \%$ ) in beef burger with added hydrogelled emulsion with chia and linseed oils as replacement of pork backfat. In addition, Fagundes et al. [27] also reported a fat reduction $(\sim 30 \%)$ in beef burgers with animal fat replacement by pork skin-canola oil mixture. Moreover, Selani et al. [30] found the same reduction $(\sim 50 \%)$ in beef burgers with fat replacement by pineapple by-product-canola oil and Alejandre et al. [29] observed the same trend in beef patties reformulated with total replacement of animal fat by gelled emulsion with algae oil ( $\sim 70 \%$ fat reduction). Similarly, in more recent research, Barros et al. [31] also noticed a significant reduction of fat content in beef burgers in which animal fat was replaced by $50 \%$ and $100 \%$ of tiger nut oil emulsion. In our case, according to the European Regulations [48] all reformulated burgers can be labeled as "low fat" burgers, because they presented a total fat amount below $3 \mathrm{~g} / 100 \mathrm{~g}$ of product.

The content of ash did not show significant differences among the deer burgers studied, ranging from 1.90 to $2.02 \mathrm{~g} / 100 \mathrm{~g}$ for LIN and TIG batches, respectively. In contrast to our results, other authors find a significant increase in ash in beef burgers with partial and total replacement of animal fat by tiger nut oil emulsion [31], while other researchers, as occurs in the present manuscript, did not find any differences in ash contents between the control formulation and treatments containing sesame oil oleogels as a partial substitute (25\% and 50\%) of animal fat in beef burgers [28].

Regarding cooking loss, linseed burgers presented the lowest values $(23.93 \% ; p<0.05)$, while the other three batches presented similar values (control $(28.31 \%)$, tiger nut $(27.27 \%)$, and chia $(27.11 \%)$ ). Our values are in disagreement with previous studies published by other authors $[8,27,28,46]$ who found different behavior in high-fat burgers, achieving higher cooking loss in the control, with significant $(p<0.05)$ difference when compared to modified burgers. In contrast with our results, the $100 \%$ of fat replacement by tiger nut oil emulsion resulted in a significant reduction of cooking loss in beef burgers [31]. Other authors reported, as occurs in the present study, that the replacement of animal fat by chia [16] or canola oil [45] did not modify cooking loss. Cooking loss can be attributed to the high loss of moisture and fat during cooking [46], however both control and reformulated deer burgers were formulated with low fat contents, which can explain that TIG and CHI did not show differences in comparison with control samples. Lower cooking loss values in reformulated burgers with linseed may be occurred because of a higher thermal stability of the microparticles which contributes to moisture retention and suggests that linseed was more effective in retaining moisture after cooking. The higher thermal stability of the linseed microparticles has been demonstrated previously [8].

Texture changes that occur in meat products by healthier fat reformulation are important challenges, especially due to its importance in sensory attributes [8]. However, in the present study the substitution of animal fat by vegetable oils did not affect textural parameters (Table 1). The present results agree with a recent study in which partial (50\%) and total $(100 \%)$ animal fat replacement by tiger nut oil did not modify texture [31]. In this study, authors also use "prosella" emulsion in the reformulation of beef burgers. However, other authors reported an increase in hardness $[8,16,27,28]$, cohesiveness [8,45], chewiness [16,27,45,46] and gumminess [27] in reformulated batches. Replacement of animal fat commonly resulted in a firmer cooked product because lower fat globules of vegetable oils increase protein-protein and protein-lipid interaction, enhancing the resistance to compression and consequently requiring more work to masticate until swallowing $[8,45,49]$. Probably, in our study this phenomenon did not occur among treatments due to the similar fat content among all batches that causes an analogous protein:lipid ratio. This higher ratio could modify the protein network (aggregated matrix) which results in a harder and more cohesive texture [50]. Hence, texture results can be considered satisfactory from the point of view of lipid reformulation since no texture modifications were observed compared to an animal fat source. Differences between studies may be due to the 
amount of animal fat replaced, percentage and type of vegetable oil studied, as well as the method of vegetable oil incorporation to the product [45].

\section{2. $\mathrm{pH}$ and Colour Parameters of Burgers During Refrigerated Storage}

The $\mathrm{pH}$ values (Table 2) only showed significant $(p<0.01)$ differences among batches on day 6 of the experiment, with control and linseed presenting numerically the lowest and highest values (5.72 vs. $5.84)$, respectively. The $\mathrm{pH}$ values significantly $(p<0.001)$ decreased, except for day 6 that had a slight increase, in all batches during the whole display (18 days). Our $\mathrm{pH}$ results agree with data reported by previous studies with fat replacement $[8,16,27,45,46]$, which published that lipid reformulation did not cause a great impact on $\mathrm{pH}$ values. However, our results ( 5.42) were lower than the range of $5.77-6.35$ normally found for this meat product according to the aforementioned studies. Nonetheless, other authors reported lower values in control than in reformulated samples [8,31].

Table 2. $\mathrm{pH}$ and color parameters of deer burgers during refrigerated storage.

\begin{tabular}{|c|c|c|c|c|c|c|c|}
\hline \multirow{2}{*}{ Parameters } & \multirow{2}{*}{ Days } & \multicolumn{4}{|c|}{ Treatments } & \multirow{2}{*}{ SEM } & \multirow{2}{*}{ Sig } \\
\hline & & $\mathrm{CON}$ & TIG & CHI & LIN & & \\
\hline \multirow{6}{*}{$\mathrm{pH}$} & 0 & $5.43^{2}$ & $5.43^{2}$ & $5.36^{2}$ & $5.48^{2}$ & 0.020 & n.s. \\
\hline & 6 & $5.72^{\mathrm{a} 3}$ & $5.79^{b c 3}$ & $5.73^{\mathrm{ab} 3}$ & $5.84^{\mathrm{c} 3}$ & 0.014 & $* *$ \\
\hline & 12 & $5.27^{1}$ & $5.31^{1}$ & $5.27^{1}$ & $5.28^{1}$ & 0.012 & n.s. \\
\hline & 18 & $5.25^{1}$ & $5.28^{1}$ & $5.24^{1}$ & $5.22^{1}$ & 0.012 & n.s. \\
\hline & SEM & 0.045 & 0.050 & 0.047 & 0.056 & & \\
\hline & Sig. & $* * *$ & $* * *$ & $* * *$ & $* * *$ & & \\
\hline \multirow{6}{*}{$L^{*}$} & 0 & 36.64 & $33.54^{1}$ & $34.74^{1}$ & $33.86^{1}$ & 0.479 & n.s. \\
\hline & 6 & 35.36 & $34.58^{1}$ & $34.83^{1}$ & $34.28^{1}$ & 0.305 & n.s. \\
\hline & 12 & 38.43 & $38.60^{2}$ & $39.26^{2}$ & $39.35^{2}$ & 0.290 & n.s. \\
\hline & 18 & 38.09 & $39.07^{2}$ & $38.83^{2}$ & $38.01^{2}$ & 0.338 & n.s. \\
\hline & SEM & 0.501 & 0.619 & 0.575 & 0.610 & & \\
\hline & Sig. & n.s. & $* * *$ & $* * *$ & $* * *$ & & \\
\hline \multirow{6}{*}{$a^{*}$} & 0 & $10.84^{\mathrm{a} 3}$ & $11.97^{b 3}$ & $12.50^{\mathrm{b} 3}$ & $12.86^{\mathrm{b} 3}$ & 0.225 & $* *$ \\
\hline & 6 & $6.82^{\mathrm{a} 2}$ & $7.98^{b 2}$ & $8.30^{\mathrm{b} 2}$ & $7.66^{\mathrm{b} 2}$ & 0.177 & $* *$ \\
\hline & 12 & $5.35^{\mathrm{a} 1}$ & $5.84^{\mathrm{ab} 1}$ & $6.35^{\mathrm{b} 1}$ & $6.25^{b 1}$ & 0.147 & $*$ \\
\hline & 18 & $5.03^{\mathrm{a} 1}$ & $5.72^{a b 1}$ & $6.33^{\mathrm{c} 1}$ & $6.05^{\mathrm{c} 1}$ & 0.167 & * \\
\hline & SEM & 0.552 & 0.590 & 0.594 & 0.641 & & \\
\hline & Sig. & $* * *$ & $* * *$ & $* * *$ & $* * *$ & & \\
\hline \multirow{6}{*}{$b^{*}$} & 0 & 12.34 & $11.32^{1}$ & $11.77^{1}$ & $12.41^{1}$ & 0.204 & n.s. \\
\hline & 6 & 13.08 & $12.35^{2}$ & $13.19^{12}$ & $12.70^{1}$ & 0.203 & n.s. \\
\hline & 12 & 13.55 & $13.56^{3}$ & $13.83^{2}$ & $14.77^{2}$ & 0.271 & n.s. \\
\hline & 18 & 13.69 & $13.88^{3}$ & $13.56^{2}$ & $13.90^{12}$ & 0.213 & n.s. \\
\hline & SEM & 0.227 & 0.266 & 0.320 & 0.310 & & \\
\hline & Sig. & n.s. & $* * *$ & $* * *$ & $*$ & & \\
\hline \multirow{5}{*}{$\Delta \mathrm{E}^{*}$} & $0-6$ & $6.28^{c}$ & $5.05^{a b 1}$ & $4.67^{\mathrm{a} 1}$ & $5.75^{b 1}$ & 0.213 & * \\
\hline & $0-12$ & $7.09^{a}$ & $8.70^{b 2}$ & $8.86^{\mathrm{b} 2}$ & $8.89^{b 2}$ & 0.230 & $* *$ \\
\hline & 0-18 & $6.26^{a}$ & $8.52 \mathrm{c} 2$ & $7.48^{\mathrm{b} 2}$ & 8.19 bc2 & 0.271 & $* *$ \\
\hline & SEM & 0.268 & 0.467 & 0.506 & 0.403 & & \\
\hline & Sig. & n.s. & $* * *$ & $* * *$ & $* * *$ & & \\
\hline
\end{tabular}

${ }_{\mathrm{a}-\mathrm{d}}$ Mean values in the same row (different batch in the same day) with different letters indicate significant difference $(p<0.05) ;{ }^{1-3}$ Mean values in the same column (same batch in different days) with different numerals indicate significant difference $(p<0.05)$; SEM: standard error of the mean; Sig.: Significance; n.s.: Not significant; ${ }^{*} p<0.05$; ${ }^{* *} p<0.01$; *** $p<0.001$. Treatments: CON: burgers prepared $100 \%$ pork fat; TIG: burgers prepared with $100 \%$ of pork fat replaced by tiger nut oil; CHI: burgers prepared with $100 \%$ of pork fat replaced by chia oil; LIN: burgers prepared with $100 \%$ of pork fat replaced by linseed oil; $L^{*}$ : Lightness; $a^{*}$ : redness; $b^{*}$ : yellowness; $\Delta E^{*}$ : total color difference. 
Concerning color parameters, fat source did not affect lightness $\left(\mathrm{L}^{*}\right)$ and yellowness $\left(\mathrm{b}^{*}\right)$ of deer burgers, since no significant $(p<0.05)$ differences were observed among batches after elaboration. In addition, $\mathrm{L}^{*}$ and $\mathrm{b}^{*}$ values of control batch did not present significant differences during the whole display (Table 2). On the contrary, all color parameters were significantly affected in deer burgers prepared with vegetable oils during the refrigerated period (18 days). The most affected color parameter was redness $\left(\mathrm{a}^{*}\right)$, which showed a reduction around $50 \%(p<0.001)$ over display. After the manufacturing process (day 0), the highest $\mathrm{a}^{*}$ value was observed in LIN group (12.86), while on day 18 the highest value (6.33) was observed for $\mathrm{CHI}$ treatment. The decrease in a* values during storage time are explained by the oxidation of the iron atom within the heme group and the formation of $\mathrm{MetMb}$ [51]. The reduction of a* values during storage was reported by several authors in pork [52,53], sheep [54-58], lamb [35] and beef burgers [57].

No significant difference $(p>0.05)$ in $L^{*}$ values among batches was observed. This fact could be due to the already discussed texture parameters (i.e., protein:fat ratio), since $L^{*}$ values are influenced by physical phenomena of light scattering in a heterogeneous food products [28]. Our results are in agreement with data reported by other authors who did not find differences in $L^{*}[45]$ and $b^{*}[8,27,28,45]$ values in meat products since the vegetable oil were utilized as partial or total replacement. On the contrary, aforementioned authors also found no significant differences in $a^{*}$ values. In addition, beef burgers with fat substitution showed a more yellowness (higher $b^{*}$ values) than the control $[16,31]$. However, other authors found significant differences $(p<0.05)$ for all color parameters between batches (conventional pork burger vs. tiger nut burger) [46]. Differences in instrumental color values between the control and the treatments $(\Delta \mathrm{E})$ were $>2$, which means that the differences identified by instrument are unlikely to be noticed by consumers [16].

\subsection{Lipid Oxidation (TBARS) of Burgers during Refrigerated Storage}

The effect of fat substitution on lipid oxidation (evaluated by TBARS index) of deer burgers is shown in Figure 1. Results displayed a significant effect $(p<0.001)$ by vegetable oil reformulation. Burgers elaborated with chia presented the highest values, followed by control, tiger nut, and linseed $(0.20>0.08>0.05>0.01 \mathrm{mg} \mathrm{MDA} / \mathrm{kg}$, respectively). TBARS values in deer burgers prepared with tiger nut and linseed presented no significant differences between them. Similarly, other authors reported in a recent study that both partial and total animal fat replacement by tiger nut oil emulsion resulted in a significantly lower TBARs values than control samples. Then, during the refrigerated period, the TBARs values of LIN and CHI batches were higher than CON and TIG treatments. This outcome is in accordance with data found by other authors who observed higher levels for lipid oxidation in meat products elaborated with chia, followed by linseed, tiger nut and pork backfat [9].

In all batches, the TBARS values increased $(p<0.001)$ during the whole display (18 days), showing the highest TBARS values at the end of storage period $(1.37,1.15,2.43$ and $2.12 \mathrm{mg} \mathrm{MDA} / \mathrm{kg}$, for CON, TIG, CHI and LIN batches, respectively). Lipid deterioration could be related with the susceptibility of PUFA-rich fats to oxidation $[8,9,58]$, considering that in the present study burgers with chia oil had $35.42 \%$ more PUFA than linseed oil, and $306.25 \%$ more PUFA than tiger nut oil. All batches were kept below the limit for the oxidation acceptability of $2.5 \mathrm{mg} \mathrm{MDA} / \mathrm{kg}$ [59]. However, other authors noted that rancid flavor deterioration could be detected at TBARS values higher than $0.6 \mathrm{mg}$ MDA $/ \mathrm{kg}$ [60]. Taking into account this threshold limit, from day 6 of the experiment all batches exceeded this deterioration level of rancid flavor. With the aim of solving high lipid oxidation, previous studies proposed the addition of natural antioxidants in the products to prevent the oxidative degradation, increasing oxidative stability of rich n-3 PUFA oils, simultaneously reducing volatile compounds derived from oxidation reactions $[9,35,47,61,62]$. Our TBARS values are lower than those described by de Carvalho et al. [35] who reported that TBARS values in lamb burgers reformulated with chia emulsion ranged between 7 and $10 \mathrm{mg} \mathrm{MDA} / \mathrm{Kg}$ after 18 days of refrigerated storage. These differences could be related with the fact that these authors formulated burgers with higher fat content $(6 \%-7 \%)$ [35] than our burgers, which results in higher lipid oxidation. 


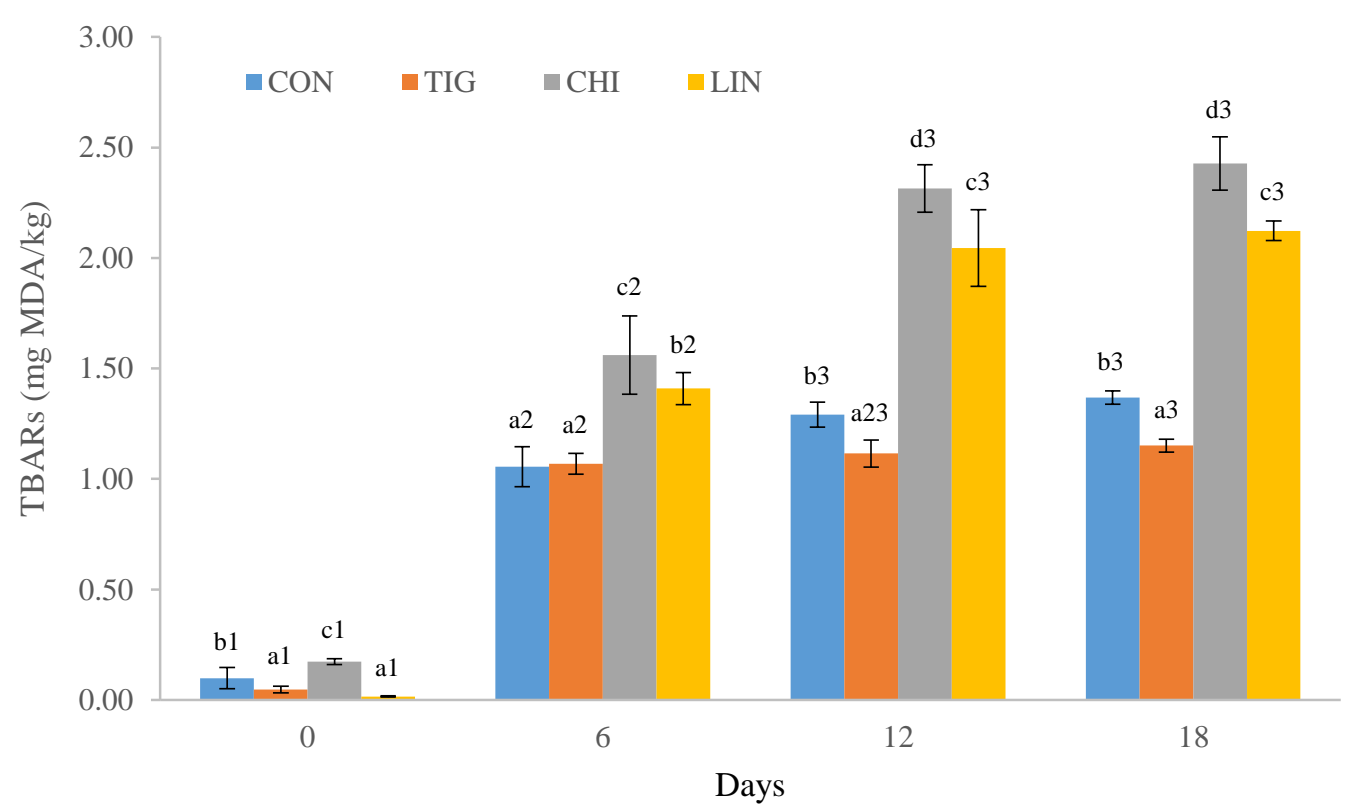

Figure 1. Thiobarbituric acid reactive substances (TBARS) values of the different formulation burgers. a-d Mean values (different batch in the same day) with different letters indicate significant difference $(p<0.05) ;{ }^{1-3}$ Mean values (same batch in different days) with different numerals indicate significant difference $(p<0.05)$. Treatments: CON: burgers prepared $100 \%$ pork fat; TIG: burgers prepared with $100 \%$ of pork fat replaced by tiger nut oil; CHI: burgers prepared with $100 \%$ of pork fat replaced by chia oil; LIN: burgers prepared with $100 \%$ of pork fat replaced by linseed oil.

\subsection{Fatty Acid Profile of Burgers}

The reformulation significantly improved the fatty acid profile of deer burgers (Table 3). In control samples the main fatty acids were SFA (40.63 g/100 g FA), followed by MUFA (40.58 g/100 g FA), and PUFA (18.79 g/100 g FA). A different fatty acid profile was observed in burgers formulated with tiger nut, in which MUFA was the most abundant fatty acids ( $52.18 \mathrm{~g} / 100 \mathrm{~g} \mathrm{FA})$, followed by SFA ( $31.48 \mathrm{~g} / 100 \mathrm{~g}$ FA) and PUFA (16.34 g/100 g FA). As expected, in samples from the other two batches, the most abundant fatty acids were PUFA in burgers prepared with chia (PUFA $>$ SFA $>$ MUFA; $65.54>19.23>15.23 \mathrm{~g} / 100 \mathrm{~g}$ FA) and linseed (PUFA $>$ SFA $>$ MUFA; $48.17>27.04>24.79 \mathrm{~g} / 100 \mathrm{~g}$ FA) oils. These results are in agreement with data reported by previous studies with beef burgers $[8,16]$.

Reformulation with chia and linseed oils resulted in a fatty acid profile modified compared to control treatment, decreasing the total amount of SFA in deer burgers by $52.50 \%$ (CHI group) and $32.50 \%$ (LIN treatment), as well as increasing PUFA by $261.11 \%$ (CHI batch) and $166.67 \%$ (LIN group). This fact is due to the particular fatty acid composition of these oils. Chia oil had very high $\alpha$-linolenic acid (C18:3n-3: 63\%) and PUFA content (82\%). Similarly, the content of C18:3n-3 in linseed oil is about $55 \%$ and PUFA reached $70 \%$ of total fatty acids [9]. In contrast, pork back fat contained high MUFA $(47 \%)$ and SFA $(\sim 35 \%)$ and very low PUFA $(18 \%)$ and n-3 content $(<1.5 \%)$ [9,32,63]. Moreover, it is important to note that these increases in PUFA content in deer burgers prepared with chia and linseed was due to the higher $(p<0.001) n$-3 PUFA contents of these samples in comparison with those observed in the CON treatment (43.77 g/100 g FA vs. $31.68 \mathrm{~g} / 100 \mathrm{~g}$ FA vs. $3.04 \mathrm{~g} / 100 \mathrm{~g}$ FA, for CHI, LIN and CON treatments, respectively). In addition, higher n-6 PUFA contents were also observed in deer burgers prepared with chia than CON samples. Additionally, another important aspect is that the content of essential fatty acids (C18:2n- 6 and C18:3n-3) was $\sim 60 \mathrm{~g} / 100 \mathrm{~g}$ FA in CHI group and $43 \mathrm{~g} / 100 \mathrm{~g}$ FA in LIN treatment. The deer burgers prepared with chia and linseed oil emulsions showed a reduction of over $30 \%$ in the SFA substituted by unsaturated fat content (when compared to the control). In this regard, these burgers can be claimed as "reduced saturated fat" according to the European Regulation [48]. Additionally, the burgers from these two batches can be also claimed 
as "high content of omega-3" because both types of deer burgers presented higher amounts than the

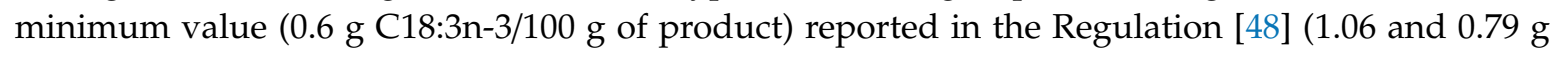
C18:3n-3/100 g of product for CHI and LIN treatments, respectively; data not shown).

Table 3. Effect of fat replacement on fatty acid profile of deer burger (g/100 g of total fatty acids).

\begin{tabular}{|c|c|c|c|c|c|c|}
\hline & \multicolumn{4}{|c|}{ Treatment } & \multirow{2}{*}{ SEM } & \multirow{2}{*}{ Sig. } \\
\hline & $\mathrm{CON}$ & TIG & CHI & LIN & & \\
\hline C14:0 & $1.89^{\mathrm{a}}$ & $1.25^{\mathrm{b}}$ & $0.57^{\mathrm{c}}$ & $1.80^{\mathrm{a}}$ & 0.134 & $* * *$ \\
\hline C14:1n-5 & $0.37^{b}$ & $0.31^{\mathrm{b}}$ & $0.14^{\mathrm{c}}$ & $0.60^{\mathrm{a}}$ & 0.045 & $* * *$ \\
\hline C15:0 & $0.29^{a}$ & $0.34^{\mathrm{a}}$ & $0.16^{\mathrm{b}}$ & $0.31^{\mathrm{a}}$ & 0.020 & $* * *$ \\
\hline C15:1n-5 & $1.09^{b}$ & $1.09^{b}$ & $1.98^{\mathrm{a}}$ & $1.22^{b}$ & 0.104 & $* * *$ \\
\hline C16:0 & $21.29^{a}$ & $15.40^{\mathrm{b}}$ & $8.09^{\mathrm{d}}$ & $12.91^{\mathrm{c}}$ & 1.108 & $* * *$ \\
\hline C16:1n-7 & $2.87^{\mathrm{a}}$ & $1.83^{\mathrm{b}}$ & $0.77^{\mathrm{c}}$ & $2.54^{\mathrm{a}}$ & 0.198 & $* * *$ \\
\hline C17:0 & $0.50^{\mathrm{a}}$ & $0.41^{b}$ & $0.24^{c}$ & $0.36^{\mathrm{b}}$ & 0.024 & $* * *$ \\
\hline C17:1n-7 & $0.27^{\mathrm{a}}$ & $0.13^{b}$ & $0.08^{c}$ & $0.12^{b}$ & 0.016 & $* * *$ \\
\hline C18:0 & $16.28^{a}$ & $12.90^{\mathrm{b}}$ & $9.51^{\mathrm{d}}$ & $11.23^{c}$ & 0.597 & $* * *$ \\
\hline 9t-C18:1 & $0.29^{a}$ & $0.21^{\mathrm{b}}$ & $0.12^{\mathrm{c}}$ & $0.19^{b}$ & 0.014 & $* * *$ \\
\hline 11t-C18:1 & $0.75^{\mathrm{a}}$ & $0.69^{a}$ & $0.30^{b}$ & $0.71^{\mathrm{a}}$ & 0.052 & $* * *$ \\
\hline C18:1n-9 & $31.68^{b}$ & $46.30^{\mathrm{a}}$ & $10.70^{\mathrm{d}}$ & $17.63^{c}$ & 3.161 & $* * *$ \\
\hline C18:1n-7 & $2.60^{\mathrm{a}}$ & $1.39^{\mathrm{c}}$ & $1.01^{\mathrm{d}}$ & $1.61^{\mathrm{b}}$ & 0.138 & $* * *$ \\
\hline C18:2n-6 & $12.35^{c}$ & $10.55^{\mathrm{d}}$ & $18.23^{\mathrm{a}}$ & $13.38^{b}$ & 0.668 & $* * *$ \\
\hline C18:3n-3 & $1.38^{\mathrm{c}}$ & $1.08^{\mathrm{c}}$ & $41.31^{\mathrm{a}}$ & $29.85^{b}$ & 4.059 & $* * *$ \\
\hline $9 \mathrm{c}, 11 \mathrm{t}-\mathrm{C} 18: 2$ & $0.16^{\mathrm{a}}$ & $0.13^{\mathrm{a}}$ & $0.08^{b}$ & $0.14^{\mathrm{a}}$ & 0.009 & $* * *$ \\
\hline C20:0 & $0.27^{\mathrm{c}}$ & $0.68^{\mathrm{a}}$ & $0.37^{b}$ & $0.19^{\mathrm{d}}$ & 0.043 & $* * *$ \\
\hline C20:1n-9 & $0.64^{\mathrm{a}}$ & $0.19^{b}$ & $0.14^{\mathrm{b}}$ & $0.15^{\mathrm{b}}$ & 0.051 & $* * *$ \\
\hline C20:2n-6 & $0.41^{\mathrm{a}}$ & $0.06^{c}$ & $0.12^{b}$ & $0.07^{\mathrm{c}}$ & 0.033 & $* * *$ \\
\hline C20:3n-6 & $0.27^{\mathrm{b}}$ & $0.30^{\mathrm{ab}}$ & $0.36^{\mathrm{a}}$ & $0.25^{b}$ & 0.016 & $*$ \\
\hline C20:4n-6 & 2.42 & 2.38 & 2.71 & 2.52 & 0.123 & n.s. \\
\hline C20:5n-3 & $0.43^{b}$ & $0.46^{\mathrm{b}}$ & $0.77^{\mathrm{a}}$ & $0.47^{\mathrm{b}}$ & 0.040 & $* * *$ \\
\hline C24:0 & n.d. d & $0.27^{\mathrm{a}}$ & $0.12^{b}$ & $0.07^{\mathrm{c}}$ & 0.023 & $* * *$ \\
\hline C22:5n-3 & 0.97 & 1.03 & 1.38 & 1.09 & 0.063 & n.s. \\
\hline$C 22: 6 n-3$ & 0.15 & 0.17 & 0.20 & 0.19 & 0.009 & n.s. \\
\hline SFA & $40.63^{\mathrm{a}}$ & $31.48^{\mathrm{b}}$ & $19.23^{d}$ & $27.04^{c}$ & 1.801 & $* * *$ \\
\hline MUFA & $40.58^{b}$ & $52.18^{a}$ & $15.23^{d}$ & $24.79^{c}$ & 3.280 & $* * *$ \\
\hline PUFA & $18.79^{c}$ & $16.34^{c}$ & $65.54^{\mathrm{a}}$ & $48.17^{b}$ & 4.748 & $* * *$ \\
\hline $\mathrm{n}-3$ & $3.04^{c}$ & $2.80^{\mathrm{c}}$ & $43.77^{\mathrm{a}}$ & $31.68^{b}$ & 4.122 & $* * *$ \\
\hline n-6 & $15.46^{b}$ & $13.28^{c}$ & $21.61^{\mathrm{a}}$ & $16.21^{\mathrm{b}}$ & 0.747 & $* * *$ \\
\hline$n-6 / n-3$ & $5.43^{\mathrm{a}}$ & $4.79^{\mathrm{a}}$ & $0.49^{b}$ & $0.51^{\mathrm{b}}$ & 0.549 & $* * *$ \\
\hline
\end{tabular}

${ }^{a-d}$ Mean values in the same row (corresponding to the same parameter) with different letter differ significantly $(p<0.05$; Duncan test); n.d.: not detected; SEM: Standard error of the mean. Sig.: Significance; n.s.: Not significant; ${ }^{*} p<0.05 ;{ }^{* * *} p<0.001$. Treatments: CON: burgers prepared 100\% pork fat; TIG: burgers prepared with $100 \%$ of pork fat replaced by tiger nut oil; CHI: burgers prepared with $100 \%$ of pork fat replaced by chia oil; LIN: burgers prepared with $100 \%$ of pork fat replaced by linseed oil.

In contrast, the replacement of animal fat by tiger nut oil decreased PUFA content $(18.79 \mathrm{~g} / 100 \mathrm{~g}$ FA vs. $16.34 \mathrm{~g} / 100 \mathrm{~g}$ FA, for CON and TIG batches, respectively). However, a significant increase in MUFA (30\%) and decrease in SFA $(22.18 \%)$ compared to control was observed. This fact is associated with the higher amount of oleic acid (C18:1n-9) present in TIG burger (46.30 g/100 g FA; Table 3). Thus, fatty acid composition of tiger nut burgers reflects the tiger nut oil fatty acids composition, because this oil had high contents of C18:1n-9 (67 g/100 g FA) [9,17,31].

In quantitative terms, C18:1n-9 > palmitic acid (C16:0) > stearic acid (C18:0) and >linoleic acid $(\mathrm{C} 18: 2 \mathrm{n}-6)$ were the major fatty acids found in CON and TIG treatments. This profile is in agreement with those reported by other authors in beef burgers manufactured with pork back fat [8]. Moreover, in a previous study, authors also found the same fatty acids profile in control and reformulated beef burgers with tiger nut oil emulsion [31]. On the other hand, C18:3n-3, C18:2n-6, C18:1n-9, C16:0 and 
C18:0 were the most abundant in CHI and LIN burgers. Thus, as a general conclusion, due to the low fat content of deer meat [25], burgers reflected the fatty acid composition of the fat or oil used in their manufacture. The same conclusions were reported by other authors in reformulated burgers $[8,16,27,31,35,45]$ and also in other meat products as pâté $[9,14,63]$, dry-cured sausages $[12,64]$ and cooked or Frankfurter type sausages [10,13].

Regarding the nutritional value of deer burgers (Table 3 ), the low $n-6 / n-3$ ratio of $\mathrm{CHI}$ and LIN treatments ( 0.49 and 0.51 , respectively) when compared to the CON and TIG batches (5.43 and 4.79, respectively) give an idea of the healthiness of the products due to the high content of $n-3$ PUFAs [16]. This high C18:3n-3 level in chia and linseed led to an increase $(p<0.001)$ in PUFA levels and a higher PUFA/SFA ratio. Recent studies concluded that the reduction in $n-6$ and $n-6 / n-3$ ratio is one of the main challenges for the development of healthier meat products, since meat products should have a maximum ratio of 4:1 [16,65,66]. According to the European Food Safety Authority—EFSA [67], there are not sufficient data to define a precise fat intake to SFA, MUFA, PUFA or n-6/n3 ratio. However, several international authorities such as EFSA, FAO and USDA recommended that SFAs intake should be as low as possible [67] or less than $10 \%$ of calories (2000 or 2500 calorie diet) by replacing them with MUFAs and PUFAs [68,69]. On the other hand, according to FAO nutritional recommendations [69], the $n-6 / n-3$ ratio should be less than 4.0. Nutritional values obtained in deer burgers reformulated with chia and linseed oil emulsion satisfied advice proposed by the international authorities (EFSA, FAO and USDA) since significant values ( $p<0.001$ ) of SFA substitution by unsaturated fats (already discussed) or lower levels than those ratios recommended $(<4.0)$ were achieved. On the contrary, both CON and TIG deer burgers exceed aforementioned recommendations by 1.43 and 0.79 , respectively.

\subsection{Sensory Analysis of Burgers}

The sensory properties of deer burgers (Table 4) were influenced by the reformulation with vegetable oils. Burgers prepared with tiger nut oil achieved the highest acceptance scores, whereas $\mathrm{CHI}$ treatment obtained the lowest $(5.3>5.0>4.9>4.0$ for TIG, CON, LIN and CHI batches, respectively). It is important to note that, although TIG burgers had the highest overall acceptance, there were no significant differences among deer burgers from TIG, CON and LIN batches, while CHI samples showed significant $(p<0.01)$ lower overall acceptability scores. These findings agree with those reported by Barros et al. [31] who observed that the partial (50\%) or total replacement of animal fat by tiger nut oil emulsion resulted in higher acceptance, but no significant differences between batches were found. In a similar way, it was reported that the use of an olive and flaxseed oil mixture as a partial substitute for animal fat did not affect the beef burgers sensory parameters [70]. The same conclusion was reported in a study in which animal fat was partially replaced by pork skin-canola oil gel. These authors reported that $50 \%$ of animal fat replacement by this mixture containing $10 \%$ or $20 \%$ of canola oil did not affect the overall acceptability [27]. Another study verified that the $50 \%$ replacement of animal fat by sesame oil oleogels was considered acceptable by consumers [28].

The greater the PUFAs content in the burger (chia) the lower evaluation on sensory attributes it received (interactive effects). Our findings are in agreement with data reported by Heck et al. [8] who observed the lowest sensorial values (unpleasant taste) for beef burgers reformulated with chia oil. These authors found the lowest sensory acceptability in unencapsulated chia and linseed oil samples, due to chia oil samples were correlated with negative descriptors, such as bitter and unpleasant taste and dry and rubbery texture [8]. In contrast, the same authors in a more recent study reported that $60 \%$ of animal replacement by hydrogelled emulsion with chia and linseed oils presented a higher acceptability compared to the control burgers [16].

An acceptable differentiation among batches was possible with PCA analysis, in which the first two components accumulated a percentage of variance $>70 \%$. Attribute maps of deer burgers showed $87.30 \%$ of total variability, since F1 explained $61.77 \%$ and F2 $25.54 \%$. The attributes more influenced by F1 were odor (raw and cooked), flavor, hardness, and greasy character, whereas visual aspect and juiciness had higher weight in F2 (Table 5). 
Furthermore, considering F1 and/or the attributes related with this axis (Figure 2), the spatial separation showed that batches were separated in two groups. One of them composed by CON, TIG and LIN batches, and the second one by CHI treatment. Taking into account the results obtained from the sensorial analysis, TIG and LIN deer burgers could be an opportunity for pork backfat replacement as fat source, since its incorporation did not modify the global acceptance.

Table 4. Acceptance scores of burger reformulation with vegetable oils.

\begin{tabular}{ccccccccc}
\hline & \multicolumn{8}{c}{ Acceptance Scores } \\
\hline & VA & OR & OC & FL & JU & FI & GC & OA \\
\hline CON & 5.3 & 5.1 & 5.4 & 5.0 & 4.9 & 5.0 & 4.9 & $5.0^{\mathrm{b}}$ \\
TIG & 5.5 & 5.1 & 5.6 & 5.4 & 5.2 & 5.1 & 5.1 & $5.3^{\mathrm{b}}$ \\
CHI & 5.8 & 4.7 & 4.6 & 4.3 & 5.2 & 4.8 & 4.8 & $4.0^{\mathrm{a}}$ \\
LIN & 5.3 & 4.6 & 5.2 & 5.1 & 5.1 & 4.9 & 5.0 & $4.9^{\mathrm{b}}$ \\
F & & & & & & & & 4.215 \\
Sig. & & & & & & & & $* *$ \\
\hline
\end{tabular}

a,b Mean values with different letters indicate significant difference $(p<0.05)$. Sig.: Significance; ${ }^{* *} p<0.01$. Treatments: CON: burgers prepared $100 \%$ pork fat; TIG: burgers prepared with $100 \%$ of pork fat replaced by tiger nut oil; CHI: burgers prepared with $100 \%$ of pork fat replaced by chia oil; LIN: burgers prepared with $100 \%$ of pork fat replaced by linseed oil. VA: visual aspect (raw burger); OR: odor (raw burger); OC: odor cooked burger; FL: flavor; JU: juiciness; FI: fibrous; GC: greasy character; OA: overall acceptability.

Table 5. Sensory properties correlation with F1 and F2 of PCA.

\begin{tabular}{ccc}
\hline & F1 & F2 \\
\hline VA & 0.298 & $\mathbf{0 . 6 9 9}$ \\
OR & $\mathbf{0 . 5 2 3}$ & 0.045 \\
OC & $\mathbf{0 . 6 6 4}$ & 0.181 \\
FL & $\mathbf{0 . 9 9 8}$ & 0.001 \\
JU & 0.075 & $\mathbf{0 . 7 3 2}$ \\
FI & $\mathbf{0 . 8 5 1}$ & 0.101 \\
GC & $\mathbf{0 . 9 1 3}$ & 0.028 \\
\hline
\end{tabular}

Treatments: CON: burgers prepared $100 \%$ pork fat; TIG: burgers prepared with $100 \%$ of pork fat replaced by tiger nut oil; CHI: burgers prepared with $100 \%$ of pork fat replaced by chia oil; LIN: burgers prepared with $100 \%$ of pork fat replaced by linseed oil. VA: visual aspect; OR: odor (raw burger); OC: odor cooked burger; FL: flavor; JU: juiciness; FI: fibrous; GC: greasy character. The attributes highlighted in italics and bold had more influence on F1 or F2 axis.

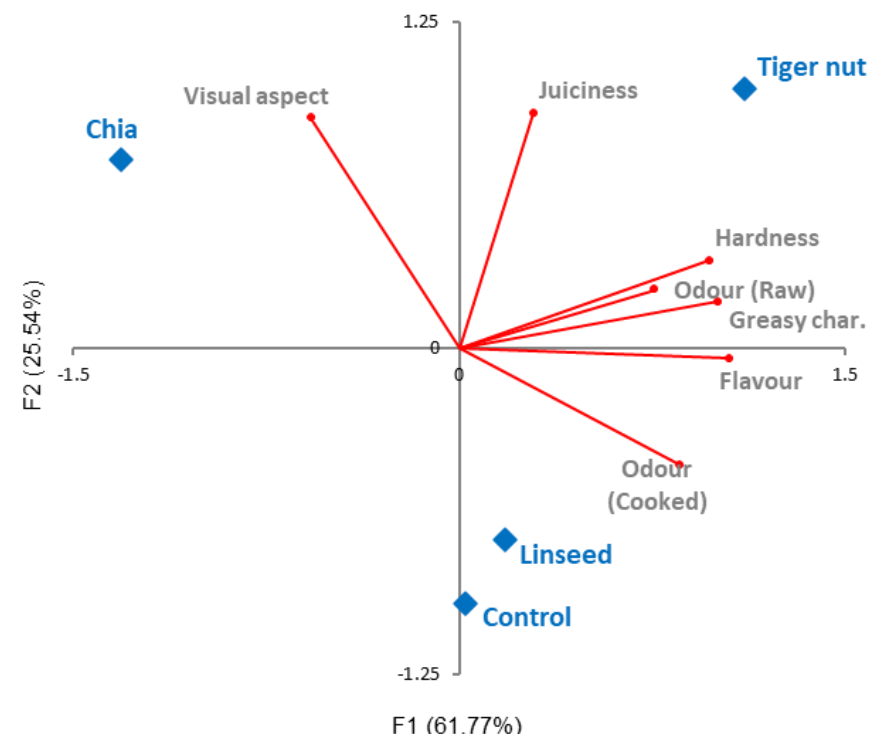

Figure 2. Projection of the sensory attributes and samples batch in the plane defined by the components. 


\section{Conclusions}

Our results demonstrated that the substitution of pork backfat by vegetable oils is a recommendable approach to obtain healthier meat products according to dietary recommendations of the main world agencies, as well growing consumer demand. Reformulation with chia and linseed improved considerably the nutritional value of deer burgers in relation to PUFAs and low n-6/n-3 ratios. Additionally, the samples of these two batches can be claimed as "high content of omega-3" and "low saturated fat" and all reformulated batches could be labelled as "low fat" burgers, which is a great advantage when marketing these deer burgers, as this product is normally perceived by the consumer as a meat product with high fat and saturated fat content. Also, results for texture were positive, considering that reformulation with vegetable oils are a challenge for the meat industry, and the present study did not find significant differences between control and reformulated batches. On the other hand, increase in PUFAs modified the shelf-life of deer burgers, being more susceptible to lipid oxidation, although the TBARS values were below $2.5 \mathrm{mg} \mathrm{MDA} / \mathrm{kg}$ in all sampling points. From the sensory point of view, the replacement of animal fat by tiger nut or linseed oil emulsion did not affect sensory properties, whereas the use of chia oil reduces the overall acceptability. Moreover, the use of deer meat in combination with tiger nut oil emulsion significantly reduced SFA and increased MUFA, while linseed oil emulsion produced a significant reduction of SFA and n-6/n-3 ratio and increased total and n-3 PUFA in comparison with control samples. Thus, with all results in mind, we can conclude that the use of tiger nut or linseed oil emulsions provides a healthy meat product for the market without reduced physiochemical or sensory properties.

Author Contributions: Conceptualization, M.P., R.D. and J.M.L.; formal analysis, M.V.-R.; writing-original draft preparation, M.V.-R., M.P., and R.D.; writing-review and editing, M.P., D.F., P.C.B.C., P.E.S.M., I.T., R.D. and J.M.L. All authors have read and agreed to the published version of the manuscript.

Funding: This work was supported by Ministerio de Economía y Competitividad (Retos-Colaboración program; Project INCYDEN, RTC-2016-5327-2).

Acknowledgments: Authors (J.M.L., M.P., D.F., P.E.S.M., P.C.B.C. and R.D.) are members of the HealthyMeat network, funded by CYTED (ref. 119RT0568). Thanks to GAIN (Axencia Galega de Innovación) for supporting this research (grant number IN607A2019/01). P.E.S.M. acknowledges postdoctoral fellowship support from Ministry of Economy and Competitiveness (MINECO, Spain) "Juan de la Cierva" program (FJCI-2016-29486). Special thanks to Cárnicas Dibe S.L. for the samples supplied for this research.

Conflicts of Interest: The authors declare no conflict of interest.

\section{References}

1. WHO The top 10 Causes of Death. Available online: https://www.who.int/news-room/fact-sheets/detail/thetop-10-causes-of-death (accessed on 1 April 2020).

2. Belc, N.; Smeu, I.; Macri, A.; Vallauri, D.; Flynn, K. Reformulating foods to meet current scientific knowledge about salt, sugar and fats. Trends Food Sci. Technol. 2019, 84, 25-28. [CrossRef]

3. Jiménez-Colmenero, F. Healthier lipid formulation approaches in meat-based functional foods. Technological options for replacement of meat fats by non-meat fats. Trends Food Sci. Technol. 2007, 18, 567-578. [CrossRef]

4. WHO 2020. Obesity and Overweight. Available online: https://www.who.int/news-room/fact-sheets/detail/ obesity-and-overweight (accessed on 1 April 2020).

5. Olmedilla-Alonso, B.; Jiménez-Colmenero, F.; Sánchez-Muniz, F.J. Development and assessment of healthy properties of meat and meat products designed as functional foods. Meat Sci. 2013, 95, 919-930. [CrossRef] [PubMed]

6. Granato, D.; Barba, F.J.; Kovačević, D.B.; Lorenzo, J.M.; Cruz, A.G.; Putnik, P. Functional Foods: Product Development, Technological Trends, Efficacy Testing, and Safety. Annu. Rev. Food Sci. Technol. 2020, 11, 93-118. [CrossRef] [PubMed]

7. Bis-Souza, C.V.; Barba, F.J.; Lorenzo, J.M.; Penna, A.L.B.; Barretto, A.C.S. New strategies for the development of innovative fermented meat products: A review regarding the incorporation of probiotics and dietary fibers. Food Rev. Int. 2019, 35, 467-484. [CrossRef] 
8. Heck, R.T.; Vendruscolo, R.G.; de Araújo Etchepare, M.; Cichoski, A.J.; de Menezes, C.R.; Barin, J.S.; Lorenzo, J.M.; Wagner, R.; Campagnol, P.C.B. Is it possible to produce a low-fat burger with a healthy n-6/n-3 PUFA ratio without affecting the technological and sensory properties? Meat Sci. 2017, 130, 16-25. [CrossRef]

9. Vargas-Ramella, M.; Pateiro, M.; Barba, F.J.; Franco, D.; Campagnol, P.C.B.; Munekata, P.E.S.; Tomasevic, I.; Domínguez, R.; Lorenzo, J.M. Microencapsulation of healthier oils to enhance the physicochemical and nutritional properties of deer pâté. LWT 2020, 125, 109223. [CrossRef]

10. De Carvalho, F.A.L.; Munekata, P.E.S.; Pateiro, M.; Campagnol, P.C.B.; Domínguez, R.; Trindade, M.A.; Lorenzo, J.M. Effect of replacing backfat with vegetable oils during the shelf-life of cooked lamb sausages. LWT 2020, 122, 109052. [CrossRef]

11. Alves, L.A.A.S.; Lorenzo, J.M.; Gonçalves, C.A.A.; Santos, B.A.; Heck, R.T.; Cichoski, A.J.; Campagnol, P.C.B. Production of healthier bologna type sausages using pork skin and green banana flour as a fat replacers. Meat Sci. 2016, 121, 73-78. [CrossRef]

12. Lorenzo, J.M.; Munekata, P.E.S.; Pateiro, M.; Campagnol, P.C.B.; Domínguez, R. Healthy Spanish salchichón enriched with encapsulated $\mathrm{n}-3$ long chain fatty acids in konjac glucomannan matrix. Food Res. Int. 2016, 89, 289-295. [CrossRef]

13. Domínguez, R.; Pateiro, M.; Agregán, R.; Lorenzo, J.M. Effect of the partial replacement of pork backfat by microencapsulated fish oil or mixed fish and olive oil on the quality of frankfurter type sausage. J. Food Sci. Technol. 2017, 54, 26-37. [CrossRef] [PubMed]

14. Domínguez, R.; Agregán, R.; Gonçalves, A.; Lorenzo, J.M.M. Effect of fat replacement by olive oil on the physico-chemical properties, fatty acids, cholesterol and tocopherol content of pâté. Grasas y Aceites 2016, 67, e133.

15. Gómez-Estaca, J.; Herrero, A.M.; Herranz, B.; Álvarez, M.D.; Jiménez-Colmenero, F.; Cofrades, S. Characterization of ethyl cellulose and beeswax oleogels and their suitability as fat replacers in healthier lipid pâtés development. Food Hydrocoll. 2019, 87, 960-969. [CrossRef]

16. Heck, R.T.; Saldaña, E.; Lorenzo, J.M.; Correa, L.P.; Fagundes, M.B.; Cichoski, A.J.; de Menezes, C.R.; Wagner, R.; Campagnol, P.C.B. Hydrogelled emulsion from chia and linseed oils: A promising strategy to produce low-fat burgers with a healthier lipid profile. Meat Sci. 2019, 156, 174-182. [CrossRef]

17. Roselló-Soto, E.; Barba, F.J.; Lorenzo, J.M.; Dominguez, R.; Pateiro, M.; Mañes, J.; Moltó, J.C. Evaluating the impact of supercritical-CO 2 pressure on the recovery and quality of oil from "horchata" by-products: Fatty acid profile, $\alpha$-tocopherol, phenolic compounds, and lipid oxidation parameters. Food Res. Int. 2019, 120, 888-894. [CrossRef]

18. Tian, Y.; Wang, F.; Xie, L.-F.; Xu, Y.-P.; Duan, P.-G. Lewis acid-catalyzed in situ transesterification/esterification of tigernut in sub/supercritical ethanol: An optimization study. Fuel 2019, 245, 96-104. [CrossRef]

19. Li, X.; Fu, J.; Wang, Y.; Ma, F.; Li, D. Preparation of low digestible and viscoelastic tigernut (Cyperus esculentus) starch by Bacillus acidopullulyticus pullulanase. Int. J. Biol. Macromol. 2017, 102, 651-657. [CrossRef]

20. Ministerio de Agricultura, Pesca y Alimentacion. Anuarios de Estadística Forestal. Available online: https:// www.mapa.gob.es/es/desarrollo-rural/estadisticas/forestal_anuarios_todos.aspx (accessed on 18 April 2020).

21. Maggiolino, A.; Pateiro, M.; Serrano, M.P.; Landete-Castillejos, T.; Domínguez, R.; García, A.; Gallego, L.; De Palo, P.; Lorenzo, J.M. Carcass and meat quality characteristics from Iberian wild red deer (Cervus elaphus) hunted at different ages. J. Sci. Food Agric. 2019, 99, 1938-1945. [CrossRef]

22. Vargas-Ramella, M.; Domínguez, R.; Pateiro, M.; Franco, D.; Barba, F.J.; Lorenzo, J.M. Chemical and physico-chemical changes during the dry-cured processing of deer loin. Int. J. Food Sci. Technol. 2020, 55, 1025-1031. [CrossRef]

23. Serrano, M.P.; Maggiolino, A.; Lorenzo, J.M.; De Palo, P.; García, A.; Landete-Castillejos, T.; Gambín, P.; Cappelli, J.; Domínguez, R.; Pérez-Barbería, F.J.; et al. Meat quality of farmed red deer fed a balanced diet: Effects of supplementation with copper bolus on different muscles. Animal 2019, 13, 888-896. [CrossRef]

24. Serrano, M.P.; Maggiolino, A.; Pateiro, M.; Landete-Castillejos, T.; Domínguez, R.; García, A.; Franco, D.; Gallego, L.; De Palo, P.; Lorenzo, J.M. Carcass Characteristics and Meat Quality of Deer. In More than Beef, Pork and Chicken-The Production, Processing, and Quality Traits of Other Sources of Meat for Human Diet; Lorenzo, J.M., Munekata, P.E.S., Barba, F., Toldrá, F., Eds.; Springer International Publishing: Cham, Switzerland, 2019; pp. 227-268, ISBN 978-3-030-05483-0. 
25. Lorenzo, J.M.; Maggiolino, A.; Gallego, L.; Pateiro, M.; Serrano, M.P.; Domínguez, R.; García, A.; Landete-Castillejos, T.; De Palo, P. Effect of age on nutritional properties of Iberian wild red deer meat. J. Sci. Food Agric. 2019, 99, 1561-1567. [CrossRef] [PubMed]

26. Serrano, M.P.; De Palo, P.; Maggiolino, A.; Pateiro, M.; Gallego, L.; Dominguez, R.; García, A.; Landete-Castillejos, T.; Lorenzo, J.M. Seasonal variations of carcass characteristics, meat quality and nutrition value in Iberian wild red deer. Span. J. Agric. Res. 2020, in press.

27. De Oliveira Fagundes, D.T.; Lorenzo, J.M.; dos Santos, B.; Fagundes, M.; Heck, R.; Cichoski, A.; Campagnol, P.C.B. Pork skin and canola oil as strategy to confer technological and nutritional advantages to burgers. Czech J. Food Sci. 2017, 35, 352-359.

28. Moghtadaei, M.; Soltanizadeh, N.; Goli, S.A.H. Production of sesame oil oleogels based on beeswax and application as partial substitutes of animal fat in beef burger. Food Res. Int. 2018, 108, 368-377. [CrossRef]

29. Alejandre, M.; Passarini, D.; Astiasarán, I.; Ansorena, D. The effect of low-fat beef patties formulated with a low-energy fat analogue enriched in long-chain polyunsaturated fatty acids on lipid oxidation and sensory attributes. Meat Sci. 2017, 134, 7-13. [CrossRef]

30. Selani, M.M.; Shirado, G.A.N.; Margiotta, G.B.; Rasera, M.L.; Marabesi, A.C.; Piedade, S.M.S.; Contreras-Castillo, C.J.; Canniatti-Brazaca, S.G. Pineapple by-product and canola oil as partial fat replacers in low-fat beef burger: Effects on oxidative stability, cholesterol content and fatty acid profile. Meat Sci. 2016, 115, 9-15. [CrossRef]

31. Barros, J.C.; Munekata, P.E.S.; de Carvalho, F.A.L.; Pateiro, M.; Barba, F.J.; Domínguez, R.; Trindade, M.A.; Lorenzo, J.M. Use of tiger nut (Cyperus esculentus L.) oil emulsion as animal fat replacement in beef burgers. Foods 2020, 9, 1-15.

32. Pires, M.A.; Barros, J.C.; Rodrigues, I.; Sichetti Munekata, P.E.; Trindade, M.A. Improving the lipid profile of bologna type sausages with Echium (Echium plantagineum L.) oil and chia (Salvia hispanica L.) flour. LWT 2020, 119, 108907. [CrossRef]

33. Lucarini, M.; Durazzo, A.; Sánchez del Pulgar, J.; Gabrielli, P.; Lombardi-Boccia, G. Determination of fatty acid content in meat and meat products: The FTIR-ATR approach. Food Chem. 2018, 267, 223-230. [CrossRef]

34. Weiss, J.; Gibis, M.; Schuh, V.; Salminen, H. Advances in ingredient and processing systems for meat and meat products. Meat Sci. 2010, 86, 196-213. [CrossRef]

35. De Carvalho, F.A.L.; Lorenzo, J.M.; Pateiro, M.; Bermúdez, R.; Purriños, L.; Trindade, M.A. Effect of guarana (Paullinia cupana) seed and pitanga (Eugenia uniflora L.) leaf extracts on lamb burgers with fat replacement by chia oil emulsion during shelf life storage at $2{ }^{\circ} \mathrm{C}$. Food Res. Int. 2019, 125, 108554. [CrossRef] [PubMed]

36. ISO 937. International Standards Meat and Meat Products-Determination of Nitrogen Content; International Organization for Standarization: Geneva, Switzerland, 1978.

37. ISO 1442. International Standards Meat and Meat Products-Determination of Moisture Content; International Organization for Standarization: Geneva, Switzerland, 1997.

38. ISO 936. International Standards Meat and Meat Products-Determination of Ash Content; International Organization for Standarization: Geneva, Switzerland, 1998.

39. AOCS. AOCS Official Procedure Am5-04. Rapid Determination of Oilffat Utilizing High Temperature Solvent Extraction; American Oil Chemists Society: Urbana, IL, USA, 2005.

40. Vyncke, W. Evaluation of the direct thiobarbituric acid extraction method for determining oxidative rancidity in mackerel. Fette Seifen Anstrichm. 1975, 77, 239-240. [CrossRef]

41. Bligh, E.G.; Dyer, W.J. A rapid method of total lipid extraction and purification. Can. J. Biochem. Physiol. 1959, 37, 911-917. [CrossRef] [PubMed]

42. Macfie, H.J.; Bratchell, N.; Greenhoff, K.; Vallis, L.V. Designs to balance the effect of order of presentation and first-order carry-over effects in hall tests. J. Sens. Stud. 1989, 4, 129-148. [CrossRef]

43. Da Silva, S.L.; Amaral, J.T.; Ribeiro, M.; Sebastião, E.E.; Vargas, C.; de Lima Franzen, F.; Schneider, G.; Lorenzo, J.M.; Fries, L.L.M.; Cichoski, A.J.; et al. Fat replacement by oleogel rich in oleic acid and its impact on the technological, nutritional, oxidative, and sensory properties of Bologna-type sausages. Meat Sci. 2019, 149, 141-148. [CrossRef]

44. Grasso, S.; Brunton, N.P.; Lyng, J.G.; Lalor, F.; Monahan, F.J. Healthy processed meat products-Regulatory, reformulation and consumer challenges. Trends Food Sci. Technol. 2014, 39, 4-17. [CrossRef] 
45. Selani, M.M.; Shirado, G.A.N.; Margiotta, G.B.; Saldaña, E.; Spada, F.P.; Piedade, S.M.S.; Contreras-Castillo, C.J.; Canniatti-Brazaca, S.G. Effects of pineapple byproduct and canola oil as fat replacers on physicochemical and sensory qualities of low-fat beef burger. Meat Sci. 2016, 112, 69-76. [CrossRef]

46. Sánchez-Zapata, E.; Muñoz, C.M.; Fuentes, E.; Fernández-López, J.; Sendra, E.; Sayas, E.; Navarro, C.; Pérez-Alvarez, J.A. Effect of tiger nut fibre on quality characteristics of pork burger. Meat Sci. 2010, 85, 70-76. [CrossRef]

47. Heck, R.T.; Lucas, B.N.; Santos, D.J.P.D.; Pinton, M.B.; Fagundes, M.B.; de Araújo Etchepare, M.; Cichoski, A.J.; de Menezes, C.R.; Barin, J.S.; Wagner, R.; et al. Oxidative stability of burgers containing chia oil microparticles enriched with rosemary by green-extraction techniques. Meat Sci. 2018, 146, 147-153. [CrossRef]

48. European PArliamnet and Council. EC Regulation (EC) No 1924/2006 of the European Parliament and of the Council of 20 December 2006 on nutrition and health claims made on foods. Off. J. Eur. Union 2006, 18, 244-259.

49. Youssef, M.K.; Barbut, S. Effects of protein level and fat/oil on emulsion stability, texture, microstructure and color of meat batters. Meat Sci. 2009, 82, 228-233. [CrossRef] [PubMed]

50. Youssef, M.K.K.; Barbut, S. Physicochemical effects of the lipid phase and protein level on meat emulsion stability, texture, and microstructure. J. Food Sci. 2010, 75, S108-S114. [CrossRef] [PubMed]

51. Faustman, C.; Sun, Q.; Mancini, R.; Suman, S.P. Myoglobin and lipid oxidation interactions: Mechanistic bases and control. Meat Sci. 2010, 86, 86-94. [CrossRef] [PubMed]

52. Lorenzo, J.M.; Vargas, F.C.; Strozzi, I.; Pateiro, M.; Furtado, M.M.; Sant'Ana, A.S.; Rocchetti, G.; Barba, F.J.; Dominguez, R.; Lucini, L.; et al. Influence of pitanga leaf extracts on lipid and protein oxidation of pork burger during shelf-life. Food Res. Int. 2018, 114, 47-54. [CrossRef]

53. Lorenzo, J.M.J.M.; Sineiro, J.; Amado, I.R.I.R.; Franco, D. Influence of natural extracts on the shelf life of modified atmosphere-packaged pork patties. Meat Sci. 2014, 96, 526-534. [CrossRef]

54. Munekata, P.E.S.; Paseto Fernandes, R.d.P.; de Melo, M.P.; Trindade, M.A.; Lorenzo, J.M. Influence of peanut skin extract on shelf-life of sheep patties. Asian Pac. J. Trop. Biomed. 2016, 6, 586-596. [CrossRef]

55. Fernandes, R.P.P.; Trindade, M.A.; Lorenzo, J.M.; de Melo, M.P. Assessment of the stability of sheep sausages with the addition of different concentrations of Origanum vulgare extract during storage. Meat Sci. 2018, 137, 244-257. [CrossRef]

56. Fernandes, R.P.P.; Trindade, M.A.; Lorenzo, J.M.; Munekata, P.E.S.; de Melo, M.P. Effects of oregano extract on oxidative, microbiological and sensory stability of sheep burgers packed in modified atmosphere. Food Control 2016, 63, 65-75. [CrossRef]

57. Zamuz, S.; López-Pedrouso, M.; Barba, F.J.; Lorenzo, J.M.; Domínguez, H.; Franco, D. Application of hull, bur and leaf chestnut extracts on the shelf-life of beef patties stored under MAP: Evaluation of their impact on physicochemical properties, lipid oxidation, antioxidant, and antimicrobial potential. Food Res. Int. 2018, 112, 263-273. [CrossRef]

58. Domínguez, R.; Pateiro, M.; Gagaoua, M.; Barba, F.J.; Zhang, W.; Lorenzo, J.M. A comprehensive review on lipid oxidation in meat and meat products. Antioxidants 2019, 8, 429. [CrossRef]

59. Zhang, Y.; Holman, B.W.B.; Ponnampalam, E.N.; Kerr, M.G.; Bailes, K.L.; Kilgannon, A.K.; Collins, D.; Hopkins, D.L. Understanding beef flavour and overall liking traits using two different methods for determination of thiobarbituric acid reactive substance (TBARS). Meat Sci. 2019, 149, 114-119. [CrossRef] [PubMed]

60. Georgantelis, D.; Blekas, G.; Katikou, P.; Ambrosiadis, I.; Fletouris, D.J. Effect of rosemary extract, chitosan and $\alpha$-tocopherol on lipid oxidation and colour stability during frozen storage of beef burgers. Meat Sci. 2007, 75, 256-264. [CrossRef] [PubMed]

61. Heck, R.T.; Fagundes, M.B.; Cichoski, A.J.; de Menezes, C.R.; Barin, J.S.; Lorenzo, J.M.; Wagner, R.; Campagnol, P.C.B. Volatile compounds and sensory profile of burgers with $50 \%$ fat replacement by microparticles of chia oil enriched with rosemary. Meat Sci. 2019, 148, 164-170. [CrossRef] [PubMed]

62. Munekata, P.E.S.; Rocchetti, G.; Pateiro, M.; Lucini, L.; Domínguez, R.; Lorenzo, J.M. Addition of plant extracts to meat and meat products to extend shelf-life and health-promoting attributes: An overview. Curr. Opin. Food Sci. 2020, 31, 81-87. [CrossRef]

63. Domínguez, R.; Pateiro, M.; Munekata, P.E.S.; Campagnol, P.C.B.; Lorenzo, J.M. Influence of partial pork backfat replacement by fish oil on nutritional and technological properties of liver pâté. Eur. J. Lipid Sci. Technol. 2017, 119, 1600178. [CrossRef] 
64. Munekata, P.E.S.; Domínguez, R.; Franco, D.; Bermúdez, R.; Trindade, M.A.; Lorenzo, J.M. Effect of natural antioxidants in Spanish salchichón elaborated with encapsulated n-3 long chain fatty acids in konjac glucomannan matrix. Meat Sci. 2017, 124, 54-60. [CrossRef]

65. Simopoulos, A.P. Omega-6/omega-3 essential fatty acid ratio and chronic diseases. Food Rev. Int. 2004, 20, 77-90. [CrossRef]

66. Simopoulos, A. An Increase in the Omega-6/Omega-3 Fatty Acid Ratio Increases the Risk for Obesity. Nutrients 2016, 8, 128. [CrossRef]

67. EFSA Dietary Reference Values for nutrients Summary report. EFSA Support. Publ. 2017, 14, e15121E.

68. USDA. 2015-2020 Dietary Guidelines for Americans; USDA: Washington, DC, USA, 2015.

69. FAO. Fat and fatty acid requirements for adults. In Fats and Fatty Acids in Human Nutrition; FAO: Rome, Italy, 2010; Volume 91.

70. Gómez, I.; Sarriés, M.V.; Ibañez, F.C.; Beriain, M.J. Quality characteristics of a low-fat beef patty enriched by polyunsaturated fatty acids and vitamin $\mathrm{D}_{3}$. J. Food Sci. 2018, 83, 454-463. [CrossRef]

(C) 2020 by the authors. Licensee MDPI, Basel, Switzerland. This article is an open access article distributed under the terms and conditions of the Creative Commons Attribution (CC BY) license (http://creativecommons.org/licenses/by/4.0/). 